\title{
Investigating Time-in-Market Effects in Kuwait Health Clubs
}

\author{
Larry P. Pleshko ${ }^{1}$, Ahmed A. Ahmed ${ }^{2}$, Awad Al-Zufairi ${ }^{3}$ \\ ${ }^{1}$ Professor of Marketing, College of Business Administration, Kuwait University \\ ${ }^{2}$ College of Business Administration, Gulf University for Science \& Technology \\ ${ }^{3}$ Associate Professor of Management, College of Business Administration, Kuwait University
}

*Corresponding Author: Larry P. Pleshko, ${ }^{I}$ Professor of Marketing ,College of Business Administration Kuwait University

\begin{abstract}
The authors study the time-in-market phenomenon among Kuwait health clubs by looking at market shares in relation to the time since entering the market. Data were collected from thirty-one health club brands with sixty-one locations throughout the country. The evidence does not support a time-in-market effect on market share. Neither simple correlations nor the interactions of time with type of health club resulted in an effect. Additionally, analyzing time-in-market group mean differences (50-50 split, 75-25 split, 90-10 split) also provided no support for an effect. Therefore, market entry timing (a pioneering effect) is not important in this setting. It may be that, in this type of service, novelty, or the marketing efforts of newer competitors, or the results of continued efforts regarding elements of the marketing mi, outweigh any advantage gained by first movers.
\end{abstract}

\section{INTRODUCTION}

Timing may play a significant role in determining the ultimate success or failure of any given adventure, whether it be personal or business in nature. A large body of academic writings exists pursuing this idea of market order-of-entry, oftentimes referred to as the first-mover effect (e.g., Robinson and Fornell, 1985; Berger and Dick, 2007; Lieberman and Montgomery, 1998; Saurez and Lanzolla, 2007; Varadarajan, et al., 2008; Rasmusen and Yoon, 2012; Tran et al., 2012). Conventional wisdom suggests that the pioneering, prospecting, or first-mover brands enjoy competitive advantages and superior performance relative to follower brands (e.g., DiBenedetto and Song, 2008; Juste et al., 2009; Pleshko and Nickerson, 2008; McDaniels and Kolari, 1987; Miles and Snow, 1978). However, other studies suggest that later entrants may be more successful than are pioneers or at least overcome any first-mover advantages (e.g., Rasmusen and Yoon, 2012; Shankar et al., 1998; Tran et al., 2012). In addition, Magnusson et al. (2009) speculate that service industries and services in developing economies may be outside the domain of a time-in-market effect, indicating successful entry may occur at any time.

Due to these contradictions, Zhao et al. (2012) call for more research into this phenomenon, particularly across more countries and categories. Up to this point, relatively little research has studied the Middle Eastern markets regarding the theory of first-movers (i.e., Heiens et al., 2015). This study attempts to address some of the aforementioned issues related to entry timings by investigating a service industry in an emerging economy. Specifically, this research will add to the entry timings literature in a different setting by investigating the relationship between time-in-market and market share performance in Kuwait health clubs.

\section{BACKGROUND}

Pioneering firms have long been studied with the resultant presumption that advantages are inherent in the early entrant brands. These advantages may or may not last, depending on a variety of factors such as the competitive situation or management activities. The first-mover advantages take a variety of forms that may prevent follower firms from achieving the same level of success. It may be that prospector firms create barriers to entry or a competitive advantage through locational advantages, technological leadership, learning curves in production or marketing, early access to human capital, superior and enduring brand image, among others (e.g., Murray et al., 2012; Frynas et al., 
2006; Lieberman and Montgomery, 1988; Kardes et al., 1993). Additionally, it appears that consumers in emerging or developing markets, such as is Kuwait, develop stronger perceptions of the initial entrants, thus leading to a more pronounced time-in-market effect (Madhy, 2011).

There is no lack of evidence supporting a positive relationship between time-in-market and performance, specifically market shares (e.g., Rodriguez-Pinto et al., 2011; Usero and Fernandez, 2009; Suarez and Lanzolla, 2007; Cui and Lui, 2005; Lieberman and Montgomery, 1988). The positive time-in-market effect on market share is suggested to be one of the most dependable empirical relationships in business (Robinson and Fornell, 1985). In addition, the positive relationship between time-in-market and market share is a primary result of the first-mover advantages, derived mainly from a pioneering brand's longer time to influence consumer perceptions and thus influence consumer learning when compared to later entrant brands (Brown and Lattin, 1994).

Nonetheless, Kerin et al. (1992) warned against assuming a relationship between order-of-entry and market share and called for qualifying the relationship by product quality or product differentiation. Vanderwerf et al. (1997) argued that there may be a methodological bias in the first-mover findings. They found in a meta-analysis the following: (a) studies using market share are more likely to reveal a relationship than studies using other measures of performance, (b) studies focused on individual industries are more likely to reveal a relationship, and conversely (c) no evidence is possible of a survivor bias if survivors are excluded.

Suarez and Lanzolla (2005) suggest that the first-mover advantage is a 'half-truth', admitting the existence of many cases where it exists but arguing that it depends on circumstances and the durability of the advantage itself. They suggest that the circumstances relevant to first-mover effects relate either to the pace of technological change or to the market evolution of specific product categories. Magnusson et al. (2009) speculates that services industries and services in developing economies are outside the domain of time-in-market effect. Suarez (2007) has called for integrating these and other relevant research streams in order to isolate the mechanisms that underpin first-mover advantages.

Nonetheless, there is indeed substantial evidence relating to service industries where a relationship between first-mover advantage and market share was revealed. Brain et.al. (1995) found in a study of banks introducing ATMs in the 1970s that earlier adopters had an advantage over later entrants. Similarly, Makadok (1998) found a strong relationship between entry-time and price advantage that resulted in a moderate effect of entry-timing on market share. In addition, Mellahi and Johnson (2000) found a positive pioneering relationship in a study about e-commerce industry and Amazon, a first-mover. Moreover, Michael (2003) found a positive relationship between entry-time and market share in restaurants franchises.

These service industry findings are not without qualifications, but are offered to counter Magnusson (2009), who generally ruled out a pioneering effect in services industries. Madi (2011) concluded that consumers in emerging or developing markets, such as is Kuwait, develop stronger perceptions of initial entrants, thus leading to a more pronounced time-in-market effect. Therefore, we propose the following research hypothesis pertaining to health clubs in the Kuwaiti market:

$\mathbf{H}_{\mathbf{R}}$ : A positive relationship exists between time-in-market and market shares.

\section{Data Collection}

The thirty-one health clubs included in the study was a comprehensive list of health club brands in operation in Kuwait (i.e., Platinum, Crowne Plaza, and Oxygen). The list of health club businesses was obtained from web-searches related to health clubs and sports clubs in Kuwait. The thirty-one health club brands operated a total of sixty-one club locations throughout the country. The largest number of locations for a brand was seven, with most being single-location businesses. The health clubs were classified into four different types of operations: crossfit, weights, combination, or other.

Data for the study was gathered by four trained researchers from Kuwait University. All of the indicators under study were obtained from either company websites or personal interviews/calls during December of 2016. As the information required to generate the indicators is not private or sensitive, no problems were encountered in data collection with no missing variables. 


\section{MEASURES}

The concepts included in the study are: (i) time-in-market (Time), (ii) market share as a percentage of total members, of total customer visits/day, of total sales/year, and average share (Share mem $_{\text {, }}$ Share $_{\text {vis }}$, Share $_{\text {sal }}$, Share $_{\text {avg }}$ ), and (iii) type of health club (Type). Time refers to the number of months in the market and is found by determining the number of months between the month of the data collection and the month of entry. Time ranged from twelve to three hundred months, with an average of 92.97 months and a standard mean error of 13.366. See Table 1 for Time frequencies. Market shares were determined in the following manner. Share $_{\text {mem(i) }}=\left(\# \operatorname{members}_{(\mathrm{i})} /\right.$ total members in all clubs $)$. Share $_{\text {vis(i) }}=\left(\#\right.$ customer visits $_{(\mathrm{i})} /$ total customer visits in all clubs $)$. Share sal(i) $_{\text {i }}=\left(\right.$ total sales $_{(\mathrm{i})} /$ total sales in all clubs). Share $\operatorname{avg(\mathrm {i})}=\left(\right.$ Share $_{m e m(\mathrm{i})}+$ Share $_{\text {vis(i) }}+$ Share $\left._{\text {sal(i) }}\right) / 3$. Coefficient alpha reliability for the first three share indicators is 0.763 and for the four market share indicators, which includes the average, is 0.882. Type was one of four classifications: (a) crossfit $(n=3)$, (b) weights $(n=7)$, (c) combination $(n=18)$, or $(d)$ other $(n=3)$. The group determined the classifications categories after studying the services and focus offerings of the health clubs.

Table1. Time-in-Market Distribution

\begin{tabular}{|l|l|l|l|}
\hline Time-in-Market (months) & Freq. & $\%$ & Cum. \% \\
\hline 12 & 1 & 3.2 & 3.2 \\
\hline 36 & 7 & 22.6 & 25.8 \\
\hline 48 & 8 & 25.8 & 51.6 \\
\hline 72 & 1 & 3.2 & 54.8 \\
\hline 84 & 2 & 6.5 & 61.3 \\
\hline 96 & 1 & 3.2 & 64.5 \\
\hline 108 & 2 & 6.5 & 71.0 \\
\hline 120 & 2 & 6.5 & 77.4 \\
\hline 144 & 2 & 6.5 & 83.9 \\
\hline 150 & 1 & 3.2 & 87.1 \\
\hline 192 & 1 & 3.2 & 90.3 \\
\hline 212 & 1 & 3.2 & 93.5 \\
\hline 300 & 2 & 6.5 & 100.0 \\
\hline Total & 31 & 100.0 & \\
\hline
\end{tabular}

\section{ANALYSES}

The analyses proceeded in three steps. First, simple correlations were computed for Time and the four market share variables. The simple correlation results are shown in Table 2. As noted, none of the four correlations of time with share is significant. Thus, no support is offered for a time-in-market effect using simple correlation.

Table2. Correlations of Time-in-Market with Market Share

\begin{tabular}{|l|l|l|l|l|l|}
\hline & & Share $_{\text {mem }}$ & Share $_{\text {vis }}$ & Share $_{\text {sal }}$ & Share $_{\text {avg }}$ \\
\hline Time & $' r^{\prime}$ & 0.155 & 0.071 & -0.054 & 0.073 \\
\hline & $' p^{\prime}$ & 0.406 & 0.703 & 0.774 & 0.698 \\
\hline & $\mathrm{n}$ & 31 & 31 & 31 & 31 \\
\hline
\end{tabular}

Second, to determine if the type of health club interacts with Time to influence market share, a simple regression was performed using Share $_{\text {avg }}$ as the dependent variable. The regression results are shown in Table 3. As noted, neither the Time variable $\left({ }^{\prime}{ }^{\prime}=0.521\right)$ nor the interaction of Time with Type $(' p '=0.384)$ exhibits a significant effect on Share $_{\text {avg }}$. Again, no support is offered for a time-in-market effect using regression analysis.

Table3. Regression Results

\begin{tabular}{|l|l|l|l|l|}
\hline Parameter & b & std. error & t & p' $^{\prime}$ \\
\hline intercept & 0.029 & 0.008 & 3.801 & 0.001 \\
\hline Time & 0 & 0 & -0.65 & 0.521 \\
\hline Time*Type & $4.97 \mathrm{E}-05$ & $5.62 \mathrm{E}-05$ & 0.885 & 0.384 \\
\hline
\end{tabular}

Third, the health clubs were grouped based on their time-in-market into follower and leader groups based on entry timings. This was done using a 50-50 Time split, a 75-25 Time split, and a 90-10 Time split. The results of these independent samples t-tests are shown in Table 4, Table 5, and Table 6. As 
noted in Table 4 regarding the 50-50 split, none of the market share indicators exhibited significant group differences. Again, no support is offered for a time-in-market effect when using a simple median split and t-tests to analyze group differences.

Table4. T-test Results using 50-50 Time Split

\begin{tabular}{|c|c|c|c|c|c|c|}
\hline Share Indicator & Group* & 'n' & Share Mean & $t^{\prime}$ & $p^{\prime}$ & Finding \\
\hline Share $_{\text {mem }}$ & $\begin{array}{l}\text { follower }(<=48) \\
\text { leader }(>48)\end{array}$ & $\begin{array}{l}16 \\
15\end{array}$ & $\begin{array}{l}0.0239 \\
0.0412\end{array}$ & -1.991 & 0.056 & no differences in share \\
\hline Share $_{\text {vis }}$ & $\begin{array}{l}\text { follower }(<=48) \\
\text { leader }(>48)\end{array}$ & $\begin{array}{l}16 \\
15\end{array}$ & $\begin{array}{l}0.0239 \\
0.0412\end{array}$ & -1.240 & 0.235 & no differences in share \\
\hline Share $_{\text {sal }}$ & $\begin{array}{l}\text { follower }(<=48) \\
\text { leader }(>48)\end{array}$ & $\begin{array}{l}16 \\
15\end{array}$ & $\begin{array}{l}0.0320 \\
0.0326\end{array}$ & -0.067 & 0.947 & no differences in share \\
\hline Share $_{\text {avg }}$ & $\begin{array}{l}\text { follower }(<=48) \\
\text { leader }(>48)\end{array}$ & $\begin{array}{l}16 \\
15\end{array}$ & $\begin{array}{l}0.0266 \\
0.0383\end{array}$ & -1.309 & 0.201 & no differences in share \\
\hline
\end{tabular}

* Note: Months since entry into the market $<=48$ or $>48$

As noted from the Table 5 regarding the 75-25 split, none of the market share indicators exhibited significant group differences. Again, no support is offered for a time-in-market effect when using a 75-25 follower-leader split and t-tests to analyze group differences.

Table5. T-test Results using 75-25 Time Split

\begin{tabular}{|c|c|c|c|c|c|c|}
\hline Share Indicator & Group* & 'n' & Share Mean & $t^{\prime}{ }^{\prime}$ & 'p' & Finding \\
\hline Share $_{\text {mem }}$ & $\begin{array}{l}\text { follower }(<=120) \\
\text { leader }(>120)\end{array}$ & 24 & $\begin{array}{l}0.0322 \\
0.0324\end{array}$ & -0.019 & 0.985 & no differences in share \\
\hline Share $_{\text {vis }}$ & $\begin{array}{l}\text { follower }(<=120) \\
\text { leader }(>120)\end{array}$ & 24 & $\begin{array}{l}0.0328 \\
0.0305\end{array}$ & 0.133 & 0.895 & no differences in share \\
\hline Share $_{\text {sal }}$ & $\begin{array}{l}\text { follower }(<=120) \\
\text { leader }(>120)\end{array}$ & 24 & $\begin{array}{l}0.0327 \\
0.0307\end{array}$ & 0.189 & 0.851 & no differences in share \\
\hline Share $_{\mathrm{avg}}$ & $\begin{array}{l}\text { follower }(<=120) \\
\text { leader }(>120)\end{array}$ & 24 & $\begin{array}{l}0.0326 \\
0.0312\end{array}$ & 0.124 & 0.902 & no differences in share \\
\hline
\end{tabular}

* Note: Months since entry into the market $<=120$ or $>120$

As noted from the Table 6 regarding the 90-10 split, none of the market share indicators exhibited significant group differences. Again, no support is offered for a time-in-market effect when using a 90-10 follower-leader split and t-tests to analyze group differences. Therefore, the findings from the group analyses indicate that time-in-market, as indicated by group entry-timings, is not related to market share. In conclusion, regarding all the analyses, no support is offered for a time-in-market effect in this category.

Table6. T-test Results using 90-10 Time Split

\begin{tabular}{|c|c|c|c|c|c|c|}
\hline Share Indicator & Group* & $n^{\prime}$ & Share Mean & ' $t$ ' & $p^{\prime}$ & Finding \\
\hline Share $_{\text {mem }}$ & $\begin{array}{l}\text { follower }(<=192) \\
\text { leader }(>192)\end{array}$ & $\begin{array}{l}28 \\
3 \\
\end{array}$ & $\begin{array}{l}0.0327 \\
0.0283 \\
\end{array}$ & 0.283 & 0.779 & no differences in share \\
\hline Share $_{\text {vis }}$ & $\begin{array}{l}\text { follower }(<=192) \\
\text { leader }(>192)\end{array}$ & $\begin{array}{l}28 \\
3 \\
\end{array}$ & $\begin{array}{l}0.0340 \\
0.0163 \\
\end{array}$ & 0.719 & 0.478 & no differences in share \\
\hline Share $_{\text {sal }}$ & $\begin{array}{l}\text { follower }(<=192) \\
\text { leader }(>192)\end{array}$ & $\begin{array}{l}28 \\
3 \\
\end{array}$ & $\begin{array}{l}0.0321 \\
0.0338 \\
\end{array}$ & -0.117 & 0.908 & no differences in share \\
\hline Share $_{\text {avg }}$ & $\begin{array}{l}\text { follower }(<=192) \\
\text { leader }(>192)\end{array}$ & $\begin{array}{l}28 \\
3 \\
\end{array}$ & $\begin{array}{l}0.0329 \\
0.0261\end{array}$ & 0.437 & 0.665 & no differences in share \\
\hline
\end{tabular}

* Note: Months since entry into the market 4192=192

\section{CONClusions \& Limitations}

The intention of this study was to investigate the time-in-market theory pertaining to a previously unstudied category in a service industry of an emerging economy: Kuwait health clubs. The findings were null for both a direct effect and any interaction effect with the type of club, suggesting that time- 
in-market is unrelated to performance as measured by market shares of Kuwaiti Dinars and number of members and customer visits, at least in this sector of the services industry in Kuwait.

The null finding is not completely unexpected. Heiens et al. (2015) found similar results for the direct effect in a previous study in Kuwait coffee shops. However, they did find an interactive effect related to marketing efforts and consumer experiences. Additionally, it may be something specific to the Kuwait market is masking a true effect. Kuwait spent nearly a decade with little change after the Iraq invasion was repelled. After that lost decade, populations and marketing infrastructure exploded with the additions of many new malls, service offerings, and general competitive offerings (Gavin, 2013; Al-Awadi, 2002). During this time of change, the Kuwaiti population faced a myriad of new choices in almost every service area, including health clubs. Thus, novelty or novelty seeking in the trial of new products or services may play a role in the null finding of a time-in-market effect (e.g., LaFerle et al., 2013; Howard and Compton, 2003).

Additionally, it may be difficult to create barriers to competitive entry in this service category (e.g., Makadok, 1998). Continual entry by new competitors would eventually siphon off customers from early entrants unless the pioneers had emphasized marketing efforts focusing on relationship marketing and/or the management continually updated design to meet customer expectations (Heiens et al., 2015). Relatedly, pioneering firms oftentimes need to develop customer switching costs in order to maintain a leadership position (e.g., Lee et al., 2001). This would require some sort of competitive advantage, whether derived from cost structure, image, design, etc. preventing users from moving to newer entrants. It may be that in these health clubs, management has not been able to enact switching costs and therefore the early entrants initial advantages become null after a time.

Also, the Magnusson, et al. (2009) speculation may be correct that service industries in developing countries are outside the domain of a time-in-market effect. In fact, Song et al. (1999), in a multicountry study, found differences regarding the way managers from Western and Asian countries view this time-in-market effect in both manufacturing and service industries. Both groups see cost and differentiation advantages as more significant in manufacturing than in services. While both groups associate pioneering with market share and profits, managers from manufacturing perceive the risks as higher in manufacturing than in services. By contrast, the cost and differentiation advantages are perceived to be higher in manufacturing than in services. Regarding cultural aspects of first-mover theory, Western manufacturing managers are shown to perceive cost advantages to be larger than do the Asian manufacturing managers (Song et al., 1999). Similarly, Song, et al. (2000), found that service managers from Western firms perceive the preemptive advantages of pioneering to be more important than do their Asian counterparts. In contrast, the services managers from Asian-Pacific firms perceive behavioral advantages as more important in their view than Western firms' managers would view them. The study also found technological advantages of pioneering are much less important to service managers than other pioneering advantages.

Not only could the services industries be outside the domain of a time-of-entry market share effect and therefore different from manufacturing industries, but the two elements of Suarez and Lanzolla' (2005) - pace of technology and market evolution - must be at work in the case of the industry we are studying. The environment of the health club market in Kuwait might be described as a calm-waters environment where no great technology lead exists and the market is not volatile even in the absence of entry barriers. According to The Suarez-Lanzolla scheme, in a calm-waters situation the advantage is short-lived and, even if attainable, not large. Also, with low barriers to entry as Makadok (1998) found, the market share advantage of the first-mover is moderate even though the price advantages may be sustainable for the pioneers. This could be the case regarding the Kuwait health-club industry.

Moreover, it is not just novelty that gives a market share advantage in this services market, ease of access must give a market share advantage as well since patrons usually frequent health clubs after work in their spare-time and attend to their social and family life and rest after that. The neighborhood club will have an advantage over far away ones. However, since the population is scattered throughout the country, as are the health clubs, there may not be any locational advantages and no resulting first-mover advantages.

The conclusions of this study are limited in a variety of ways. The small sample size, while exhaustive in Kuwait, may lead to Type 2 errors: not being able to reject a false null hypothesis. The data 
collection took place at one time period, while a longitudinal study may lead to differing results. Other concepts that may influence the time-in-market effect, such as marketing efforts or loyalty rates, were not investigated. This eliminates the possibility of finding interactions or other effects with those variables. Finally, the focus on a single category might ignore the possibility of time-in-market effects in other service categories.

\section{REFERENCES}

[1] Al-Awadi, Ahmad (2002). A proposed model of consumer loyalty in the retailing sector based on the Kuwaiti experience. Total Quality Management, 13 (7), 1035-1046.

[2] Berger, Allen N. \& Astrid A. Dick (2007). Entry into banking markets and the early-mover advantage. Journal of Money, Credit, and Banking, 39 (4), 775-807.

[3] Brain, L. Dos Santos \& Ken Peffers (1995). Rewards to investors in innovative information technology applications: First movers and early followers in ATMs. Organization Science, 6 (3), 241-259.

[4] Brown, C.L. \& J.M. Lattin (1994). Investigating the relationship between time-in-market and pioneering advantages. Management Science, 40 (10), 1361-1369.

[5] Cui, Geng \& Hon-Kwon Lui (2005). Order of entry and performance in multinational corporations in an emerging market: A contingent resource perspective. Journal of International Marketing, 13 (4), 28-56.

[6] Di Benedetto, C. Anthony \& Michael Song (2008). Managerial perceptions of global pioneering advantage: Theoretical framework and empirical evidence in the U.S. and Korea. Industrial Marketing Management, 37 (7), 863-872.

[7] Frynas, Jędrzej George, Kamel Mellahi \& Geoffrey Allen Pigman (2006). First-mover advantages in international business and firm-specific political resources. Strategic Management Journal, 27 (4), 321345.

[8] Gavin, James (2013). Kuwait's retail opportunity. Middle East Economic Digest, 57 (25), 40-41.

[9] Heiens, Richard A., Larry P. Pleshko, \& Awad Al-Zufairi (2015). Making up lost ground: The relative advantage of customer relationship management versus time-in-market. Journal of International Consumer Marketing, 27, 84-96.

[10] Howard, D.R. \& J.L. Crompton (2003). An empirical review of the stadium novelty effect. Sport Marketing Quarterly, 12 (2), 11-16.

[11] Juste, Victoria Bordonaba, Laura Lucia-Palacios \& Yolanda Polo-Redondo (2009). Franchise firm entry time influence on long-term survival. International Journal of Retail and Distribution Management, 37 (2), 106-125.

[12] Kardes, Frank R., Gurumurthy Kalyanaram, Murali Chandrashekaran, \& Ronald J. Dornoff (1993). Brand retrieval, consideration set composition, consumer choice, and the pioneering advantage. Journal of Consumer Research, 20 (June), 62-75.

[13] Kerin, Roger A., P. Rajan Varadarajan, \& Robert A. Peterson (1992). First-mover advantage: A synthesis, conceptual framework, and research propositions. Journal of Marketing, 56 (4), 33-52.

[14] LaFerle, C., G. Kuber, \& S.M. Edwards (2013). Factors impacting responses to cause-related marketing in India and the United States: Novelty, altruistic motives, and company origin. Journal of Business Research, 66 (3), 364-373.

[15] Lee, Jonathan, Janghyuk Lee, \& Lawrence Feick (2001). The impact of switching costs on the customer satisfaction-loyalty link: Mobile phone service in France. Journal of Services Marketing, 15 (1), 35-48.

[16] Lieberman, Marvin B. \& David Montgomery (1988). First-mover advantages. Strategic Management Journal, 9 (5), 41-58.

[17] Madhy, Tarek T. (2011). Does it pay to be first? A cross-national comparison of mature and emerging market consumer attitudes toward pioneer and follower brands. Journal of International Consumer Marketing, 23 (3), 276-296.

[18] Magnusson, Peter, Stanford A. Westjohn, \& David J. Boggs (2009). Order-of-entry effects for service firms in developing markets: An examination of multinational advertising agencies. Journal of International Marketing, 17 (2), 23-41.

[19] Magnusson, Peter, Stanford A. Westjohn, Geoffrey L. Gordon, \& Timothy W. Aurand (2012). Environmental dynamics and first-mover advantages in emerging markets. Marketing Management Journal, 22 (1), 17-34.

[20] Makadok, R. (1998),. Can first-mover and early-mover advantages be sustained in an industry with low barriers to entry/imitation? Strategic Management Journal, 19 (7), 683-696.

[21] McDaniels, Stephen W. \& James W. Kolari (1987). Marketing strategy implications of the Miles and Snow strategic typology. Journal of Marketing, 51 (4), 19-30. 
[22] Mellahi, Kamel, \& Michael Johnson (2000). Does it pay to be a first-mover in e-commerce? The case of Amazon.com. Management Decisions, 38 (7), 445-452.

[23] Michael, Stephen C. (2003),. First-mover advantage through franchising. Journal of Business Venturing, 18 (1), 61-80.

[24] Miles, R.E. \& C.C Snow (1978). Organizational strategy, structure, and process. New York: McGrawHill.

[25] Murray, Janet Y., Min Ju \& Gerald Yong Gao (2012). Foreign market entry timing revisited: Trade-off between market share performance and firm survival. Journal of International Marketing, 20 (3), 50-64.

[26] Pleshko, Larry P. \& Inge Nickerson (2008). Strategic orientation, organizational structure, and the associated effects on performance in industrial firms. Academy of Strategic Management Journal, 7, 95110.

[27] Rasmusen, Eric \& Young-Ro Yoon (2012). First versus second mover advantage with information asymmetry about the profitability of new markets. The Journal of Industrial Economics, 60 (3), 374-405.

[28] Robinson, William T. \& Claes Fornell (1985). Sources of market pioneer advantage in consumer goods industries. Journal of Marketing Research, 22 (3), 305-317.

[29] Rodriguez-Pinto, Javier, Pilar Carbonell, \& Ana I. Rodriguez-Escudero (2011). Speed or quality? How the order of market entry Influences the relationship between market orientation and new product performance. International Journal of Research in Marketing, 28 (1), 145-154.

[30] Suarez, Fernando \& Gianvito Lanzolla (2005). The half-truth of first-mover advantage. Harvard Business Review, April, 121-127.

[31] Suarez, Fernando F. \& Gianvito Lanzolla (2007). The role of environmental dynamics in building a first mover advantage theory. Academy of Management Review, 32 (2), 377-392.

[32] Shankar, Venkatesh, Gregory S. Carpenter, \& Lakshman Krishnamurthi (1998). Late mover advantage: How innovative late entrants outsell pioneers. Journal of Marketing Research, 35 (1), 54-70.

[33] Song, X. Michael, Anthony Di Benedetto \& Yuzhen Liza Zhao (1999). Pioneering advantages in manufacturing and service industries: Empirical evidence from nine countries. Strategic Management Journal, 20 (9), 811-836.

A. Benedetto, \& Liza Z. Song (2000). Pioneering advantage in new service development: A multi-country study on managerial perspectives. Journal of Product Innovation Management, 17 (5), 323-409.

[34] Tran, Vinh Du, David S. Sibley, \& Simon Wilkie (2012). Second mover advantage and entry timing. The Journal of Industrial Economics, 60 (3), 517-535.

[35] Usero, Belen \& Zulima Fernandez (2009). First come, first served: How market and non-market actions influence pioneer market share. Journal of Business Research, 62 (11), 1139-1145.

[36] Varadarajan, Rajan, Manjit S. Yadav, \& Venkatesh Shankar (2008). First-mover advantages in an internetenabled market environment: Conceptual framework and propositions. Journal of the Academy of Marketing Science, 36 (3), 293-308.

[37] Vanderwerf, Peter A. \& John F. Mahon (1997). Meta-analysis of the impact of research methods on findings of first-mover advantage. Management Science, 43, 1510-1519.

[38] Zhao, Y. Lisa, O. Homer Erekson, Tang Wang, \& Michael Song (2012). Pioneering advantages and entrepreneurs' first-mover decisions: An empirical investigation for the United States and China. Journal of Product Innovation Management, 29 (1), 190-210.

\section{AUTHORS' BIOGRAPHY}

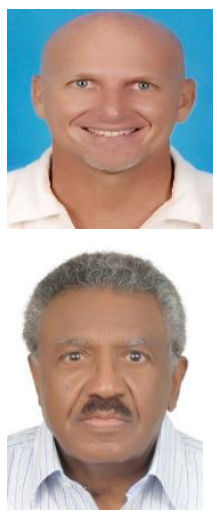

Dr. Pleshko, received his Ph.D. from Florida State University and he presently serves as Professor of Marketing at Kuwait University. He specializes in marketing strategy research related to firm performance. He has worked at universities in Australia, Saudi Arabia, the USA, United Arab Emirates, Kuwait, and Jamaica.

Dr. Ahmed, received his Ph.D. from the University of Pennsylvania Wharton School and currently serves as Professor of Management at Kuwait University. His research, which has been published in many leading journals, has focused on international business. Prof Ahmed has also taught in both American and Middle Eastern universities. 


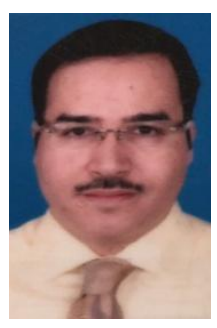

Dr. Al-Zufairi, received his Ph. D. from Saint Louis University and currently serves as Associate Professor of Management at Kuwait University and Department Head. His research interests include strategic management, HRM and ethics.

Citation: Larry P., Pleshko et al. "Investigating Time-In-Market Effects in Kuwait Health Clubs." International Journal of Managerial Studies and Research (IJMSR), vol 5, no. 11, 2017, pp. 97-104. doi:http://dx.doi.org/10.20431/2349-0349.0511011.

Copyright: (1) 2017 Authors. This is an open-access article distributed under the terms of the Creative Commons Attribution License, which permits unrestricted use, distribution, and reproduction in any medium, provided the original author and source are credited. 